\title{
Current Knowledge on Honey and Its Derivatives with Genomic Stability: A Mini Review
}

\author{
Malisanurhidayu Yaacob ${ }^{1,4}$, Anne Jesscy Stanis ${ }^{1}$, Nor Fadilah Rajab ${ }^{2}$, Suzana Shahar ${ }^{3}$ \& Razinah Sharif ${ }^{1}$ \\ ${ }^{1}$ Programof Nutritional Sciences, Faculty of Health Sciences, Universiti Kebangsaan Malaysia, Kuala Lumpur, \\ Malaysia \\ ${ }^{2}$ Program of Biomedical Science, Faculty of Health Sciences, Universiti Kebangsaan Malaysia, Kuala Lumpur, \\ Malaysia \\ ${ }^{3}$ Program of Dietetics, Faculty of Health Sciences, Universiti Kebangsaan Malaysia, Kuala Lumpur, Malaysia \\ ${ }^{4}$ Faculty of Health Sciences, Universiti Sains Islam Malaysia, Malaysia \\ Correspondence: Razinah Sharif, Program of Nutritional Sciences, Faculty of Health Sciences, Universiti \\ Kebangsaan Malaysia, Kuala Lumpur 50300, Malaysia. Tel: 60-392-897-259. E-mail: razinah@ukm.edu.my
}

Received: October 3, 2017

Accepted: December 21, 2017

Online Published: December 31, 2017

doi:10.5539/jas.v9n13p145

URL: https://doi.org/10.5539/jas.v9n13p145

\begin{abstract}
Genome health is an important factor that plays a role in various degenerative diseases. Instability of genome is the prevalence of mutation within the genome such as changed in nucleic acid and chromosomal arrangement and also the presence of abnormal number of chromosome in cell. Therefore, several method were used to overcome this problem and one of them is by using natural product such as honey, propolis, bee pollen and royal jelly that is high in antioxidant. Those are products that derive from honey bee and had been used as food supplement to increase the quality of life. Therefore, this systematic review provides the updates on the potential of honey bee products to decrease DNA damage both in in vivo and in vitro approaches. Search term of "honey", "propolis", "bee pollen", royal jelly", "DNA damage", "genome integrity", and "telomere" were used for searching purpose in three databases (Scopus, Pubmed and Medline) and also Google Scholar. All the published articles were assessed using PRISMA guidelines and finally after the eligibility process, only 34 published articles were selected for this review. Based on the reports, the product from the honey bee decrease the genome related diseases by reducing the accumulation of free radical, increase the DNA repair protein expression and decrease the telomerase activity in the cell. This provides a large gap in the research field focusing on the effect of those derivatives from bees on genomic stability.
\end{abstract}

Keywords: genome integrity, DNA damage, telomerase, honey, bee pollen, propolis

\section{Introduction}

DNA damage had been widely known as the cause of cancer and other age-related diseases (Hoeijmakers, 2009). Cancer and aging mostly associated to the genomic instability in the body. The genome instability refers to changes in the genome during the cell cycle process and the ultimate cause for tumorigenesis (Shen, 2011) and age-related diseases (Lombard et al., 2005). Normally during the cell division process, the cell genetic content will divide into two daughter cells. Each daughter cell will have the same genetic content as their parent cell (Shen, 2011). But there were several mutation such as mutations on specific genes, amplification, deletions, rearrangements of chromosome segments, gain or loss of an entire chromosome which will result from the failure in division process and lead to the several diseases (Shen, 2011).

The development of cancer due to genomic instability had been studied since several years ago (Sharif et al., 2012). Nowadays cancer known as a disease caused by genomic and epigenomic alteration and will affect the gene expression (Sharif et al., 2012). Meanwhile aging in eukaryotic organisms has been programmed in genomic, but disclosure to the harmful agents might increase the rate of aging in eukaryotic organisms (Lombard et al., 2005). Generally, aging is a cause of DNA damage, but genomic instability also plays a major contributor to aging (Lombard et al., 2005). There are several factors that contributed to DNA damage such as from exogenous sources and endogenous sources. Exogenous sources such as radiation, pollution, smoking, genotoxic drugs and mutagenic food are the main factors of developing the oxidative damage in cell (Haza \& Morales, 
2013; Lombard et al., 2005). Meanwhile endogenous sources, such as replication mistake, spontaneous chemical changes during replication also can lead to DNA damage (Lombard et al., 2005; Tsai et al., 2012). These factors will trigger the production of reactive oxygen species (ROS) and the imbalance between ROS and antioxidant will result in variety of illness (Cheng et al., 2017).

Consuming food that contains antioxidant may reduce the ROS against DNA and can protect DNA from damage (Duthie et al., 1996). Honey and its derivatives such as royal jelly, propolis and bee pollen has higher antioxidant capacity. Commonly it had been used for medicinal purposes to treat several health problems (Kustiawan et al., 2014; Pérez-pérez et al., 2013). Briefly, honey can inhibit oxidative stress by attacking $\mathrm{OONO}-\mathrm{O}_{2}$ free radical and non-free radicals such as NO (Lombard et al., 2005), induce the oxidative damage response by regulating Nrf2 protein (Khuzaimah et al., 2015) and lead to expression of DNA repair enzyme (Turan et al., 2015). This review aims to prove current scientific evidence regarding the effect of honey and its derivatives on genome health.

\section{Method}

\subsection{Search Strategy}

Databases namely Scopus, PubMed and Medline were used for searching the related articles from established data until October 2017. Google Scholar was also used for additional literature articles searching purposes. The keywords were adjusted to suit with the subject headings for each database to make sure all the relevant data were included during searching strategies. The search terms included "honey", "propolis", "bee pollen", "royal jelly", "DNA damage", "genome integrity" and "telomere". The suitable published articles were re-assessed to verify the search string. In addition, all the related published articles were also included in this literature reports. Final published articles were exported into an Endnote library to remove any duplicates.

\subsection{Inclusion Criteria}

All the honey types and its derivatives such as propolis, bee pollen and royal jelly were included in this study. Published articles of honey and its derivatives on the genome health either in vitro or in vivo were included. Randomized controlled trial (RCT's) also included in this study. All English and Malay literature reports were taken into consideration.

\subsection{Exclusion Criteria}

The published articles on bioactive component, antimicrobial, anti-inflammatory, and behavior study of the honey bee were excluded from this study. Case reports and case series were excluded from this study.

\subsection{Study Selection}

The searching of related published articles was screened by authors. Endnote software was used to filter out all duplicates articles and followed by manual verification to make sure all duplicates were removed. Relevant published articles were chosen from the databases based on the title, abstract, and retrieval of the full article. Finally, the articles that do not comply to the inclusion criteria were rejected and selected articles were downloaded for analysis.

\subsection{Data Organization and Reporting}

The information retrieved from each study were analyzed and re-arranged based on author's name and year of publication, study population, type of honey bee product, method and outcomes. The PRISMA guidelines were used to analyze the selected literature reports (http://www.prisma-statement.org/statement.htm).

\section{Results}

\subsection{Descriptive of Selected Studies}

Figure 1 is an illustration of the procedure taken for the study selection based on PRISMA guidelines. A total of 157 literature reports were found in 3 differences databases and a Google Scholar. Seventy three published articles were taken into consideration after duplicates removal. Then, 39 articles that does not fit the inclusion criteria were excluded. Finally, 34 published articles were reassessed for eligibility. All the 34 published articles were arranged accordingly for further analysis as summarized in Tables 1 and 2. 


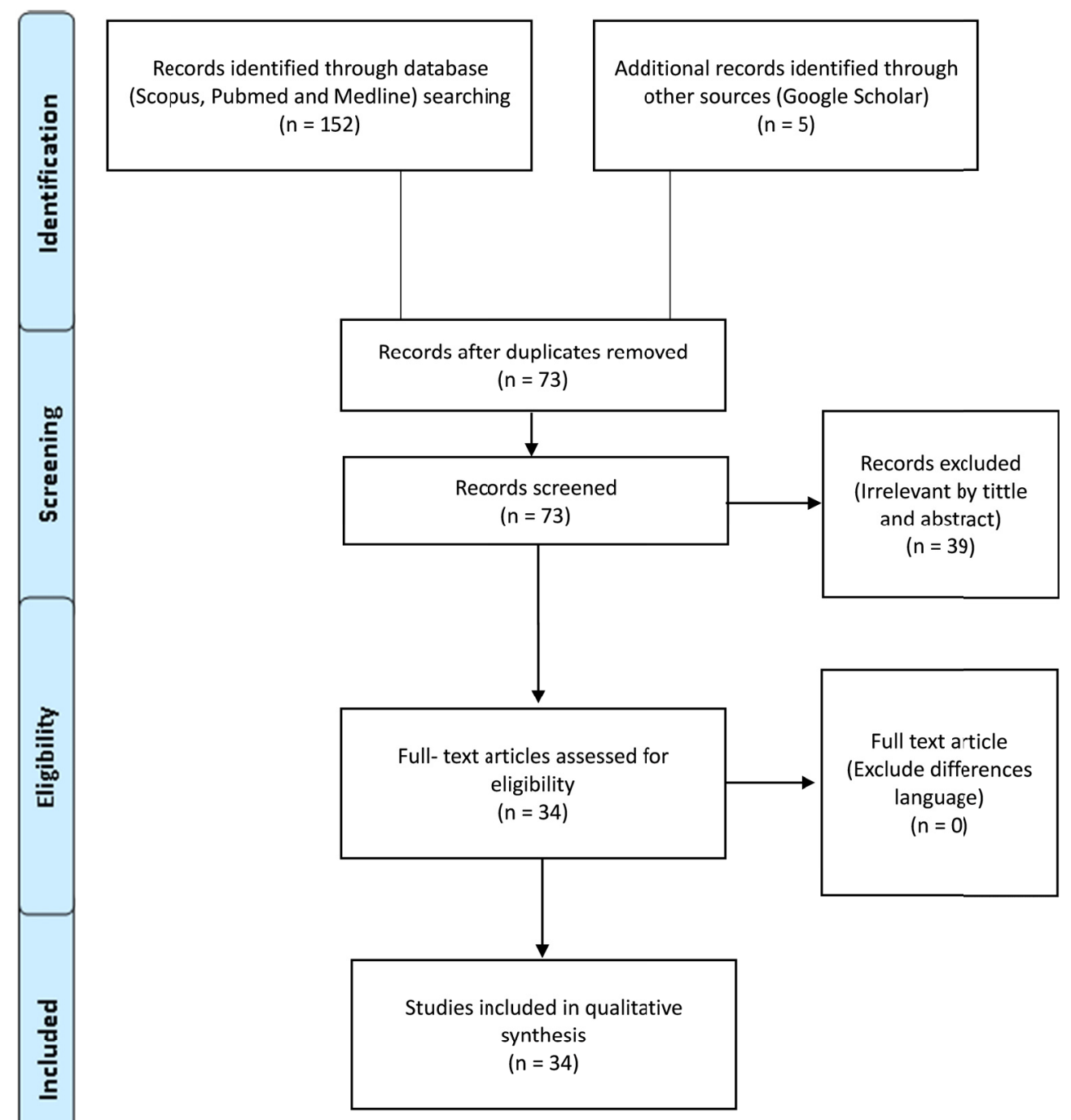

Figure 1. Flowchart of search strategy and selection process 
Table 1. In vivo studies on protective of honey and it's derivatives to DNA damage

\begin{tabular}{|c|c|c|c|c|}
\hline Authors & Study population & Types & Method & Outcomes \\
\hline Kumari et al. (2017) & Swiss albino mice & Indian propolis & $\begin{array}{l}\text { Chromatin } \\
\text { dispersion test }\end{array}$ & $\begin{array}{l}\text { Indian propolis able to reduce DNA damage } \\
\text { as well as decrease the oxidative stress. }\end{array}$ \\
\hline $\begin{array}{l}\text { Hajizadeh Maleki } \\
\text { et al. (2016) }\end{array}$ & $\begin{array}{l}\text { Healthy male } \\
\text { long-distance road cyclists }\end{array}$ & Honey & $\begin{array}{l}\text { Alkaline Comet } \\
\text { assay }\end{array}$ & $\begin{array}{l}\text { Honey attenuates oxidative stress and } \\
\text { lymphocytes DNA damage after exercise. }\end{array}$ \\
\hline Fahmy et al. (2015) & Male white Swiss mice & $\begin{array}{l}\text { Honey bee, royal } \\
\text { jelly and pollen } \\
\text { grains (mixture) }\end{array}$ & $\begin{array}{l}\text { DNA fragmented } \\
\text { assay }\end{array}$ & $\begin{array}{l}\text { Mixture of honey bee can attenuates the } \\
\text { genotoxic side effect of chemotherapeutic } \\
\text { drug. }\end{array}$ \\
\hline Cheng et al. (2015) & Male Kunming mice & $\begin{array}{l}\text { Buckwheat } \\
\text { honey }\end{array}$ & $\begin{array}{l}\text { Alkaline Comet } \\
\text { assay }\end{array}$ & $\begin{array}{l}\text { DNA damage reduce due to honey's } \\
\text { phenolic content. }\end{array}$ \\
\hline Sahhugi et al. (2014) & Male Sprague-Dawley rats & Gelam honey & $\begin{array}{l}\text { Alkaline Comet } \\
\text { assay }\end{array}$ & $\begin{array}{l}\text { Gelam honey can reduce DNA damage in } \\
\text { young and aged rats. }\end{array}$ \\
\hline Kandiel et al. (2014) & Nile tilapia & Honeybee pollen & Micronucleus & $\begin{array}{l}\text { Bee pollen minimize the health hazardous of } \\
\text { malathion which can induce DNA damage. }\end{array}$ \\
\hline Oršolić et al. (2013) & Male CBA inbred mice & Propolis & $\begin{array}{l}\text { Alkaline Comet } \\
\text { assay }\end{array}$ & $\begin{array}{l}\text { Propolis reduced DNA damaged in } \\
\text { peripheral lymphocytes of diabetic mice. }\end{array}$ \\
\hline Jubri et al. (2013) & Male Sprague-Dawley rats & Manuka honey & $\begin{array}{l}\text { Alkaline Comet } \\
\text { assay }\end{array}$ & $\begin{array}{l}\text { Manuka honey reduce DNA damaged in } \\
\text { young and middle age rats. }\end{array}$ \\
\hline Türkez et al. (2013) & Male Sprague-Dawley rats & Propolis & $\begin{array}{l}\text { Micronucleus } \\
\text { assay }\end{array}$ & $\begin{array}{l}\text { Propolis able to antagonize } \\
\text { Tetrachlorodibenzo-p-dioxin toxicity in the } \\
\text { rat's liver. }\end{array}$ \\
\hline Yao et al. (2011) & Male Sprague-Dawley rats & Gelam honey & $\begin{array}{l}\text { Alkaline Comet } \\
\text { assay }\end{array}$ & $\begin{array}{l}\text { Gelam honey reduce oxidative damage in } \\
\text { young and middle age rats. }\end{array}$ \\
\hline $\begin{array}{l}\text { Cavuşoğlu et al. } \\
\text { (2009) }\end{array}$ & $\begin{array}{l}\text { Male Mus musculus var. } \\
\text { Albinos (mice) }\end{array}$ & Royal Jelly & $\begin{array}{l}\text { Micronucleus } \\
\text { assay }\end{array}$ & $\begin{array}{l}\text { Royal Jelly has a protective role against } \\
\text { Cadmium induced genotoxicity. }\end{array}$ \\
\hline Pereira et al. (2008) & Swiss mice & $\begin{array}{l}\text { Brazilian green } \\
\text { propolis }\end{array}$ & $\begin{array}{l}\text { Alkaline Comet } \\
\text { assay }\end{array}$ & $\begin{array}{l}\text { Green propolis increased DNA damage in } \\
\text { the peripheral blood cells of mice when } \\
\text { imposed with high doses. }\end{array}$ \\
\hline Benkovic et al.(2008) & Male CBA mice & Propolis & Alakine Comet & Decrease DNA damage in white blood cells. \\
\hline Alves De Lima et al. & Wistar rats & Propolis & $\begin{array}{l}\text { Alkaline Comet } \\
\text { assay }\end{array}$ & $\begin{array}{l}\text { Propolis modulated Dimethylhydrazine } \\
\text { effect in colon cells. }\end{array}$ \\
\hline
\end{tabular}


Table 2. In vitro studies on protective of honey and it's derivatives to DNA damage

\begin{tabular}{|c|c|c|c|c|}
\hline Authors & Study population & Types & Method & Outcomes \\
\hline Cheng et al. (2017) & ice lymphocytes & oney & $\begin{array}{l}\text { Alkaline Comet } \\
\text { assay }\end{array}$ & $\begin{array}{l}\text { Honey can protect cell from DNA damage by } \\
\text { scavenging hydrogen peroxide. }\end{array}$ \\
\hline Alleva et al. (2016) & $\begin{array}{l}\text { Human bronchial epithelial cell } \\
\text { (BEAS-2B) and neuronal cell line } \\
\text { (SHSY-5Y) }\end{array}$ & Honey & $\begin{array}{l}\text { DNA fragmented } \\
\text { assay }\end{array}$ & $\begin{array}{l}\text { Honey reduced DNA damage on } \\
\text { pesticide-induce DNA damaged. }\end{array}$ \\
\hline Yalcin et al. (2016) & $\begin{array}{l}\text { Foreskin fibroblast cells } \\
\text { (CRL-2522) }\end{array}$ & Propolis & $\begin{array}{l}\text { Alkaline Comet } \\
\text { assay }\end{array}$ & $\begin{array}{l}\text { Propolis can prevent } \Upsilon \text {-ray induced DNA } \\
\text { damage. }\end{array}$ \\
\hline Roberto et al. (2016) & Rat hepatoma cell line & Propolis & $\begin{array}{l}\text { Alkaline Comet } \\
\text { assay }\end{array}$ & Propolis show the reduction of DNA damage. \\
\hline Sherin et al. (2015) & $\lambda$ DNA (pBR322) & Honey & $\begin{array}{l}\text { DNA fragmented } \\
\text { assay }\end{array}$ & Honey protect DNA from oxidative damage. \\
\hline Afroz et al. (2016) & $\lambda \mathrm{DNA}(\mathrm{pBR} 322)$ & Honey & $\begin{array}{l}\text { DNA fragmented } \\
\text { assay }\end{array}$ & $\begin{array}{l}\text { Reduce DNA damage on dose dependent } \\
\text { manner. }\end{array}$ \\
\hline Turan et al. (2015) & Fibroblast cell & Propolis & $\begin{array}{l}\text { Alkaline Comet } \\
\text { assay }\end{array}$ & $\begin{array}{l}\text { Propolis decrease DNA damage and increase } \\
\text { DNA repair enzyme. }\end{array}$ \\
\hline $\begin{array}{l}\text { Yaacob \& Ismail } \\
\text { (2014) }\end{array}$ & $\begin{array}{l}\text { Breast cancer (MCF-7) and } \\
\text { non-cancerous epithelial cell line } \\
(\mathrm{MCF}-10 \mathrm{~A})\end{array}$ & Tualang honey & $\begin{array}{l}\text { Alkaline Comet } \\
\text { assay }\end{array}$ & $\begin{array}{l}\text { Tualang honey enhanced the } \\
\text { 4-hydroxytamoxifen induced DNA damage in } \\
\text { cancer cell and induce the genotoxic effect } \\
\text { 4-hydroxytamoxifen in non-cancerous cells. }\end{array}$ \\
\hline Habib et al. (2014) & $\lambda$ DNA (pBR322) & Honey & $\begin{array}{l}\text { DNA fragmented } \\
\text { assay }\end{array}$ & Honey decreased DNA damage. \\
\hline Cheng et al. (2013) & $\lambda$ DNA (pBR322) & Bee pollen & $\begin{array}{l}\text { Alkaline Comet } \\
\text { assay }\end{array}$ & $\begin{array}{l}\text { Bee pollen protect DNA from being damaged } \\
\text { by hydroxyl radical. }\end{array}$ \\
\hline Haza \& Morales & $\begin{array}{l}\text { Human hepatocellular carcinoma } \\
\text { (HepG2) cells }\end{array}$ & Honey & Alkaline Comet & $\begin{array}{l}\text { Honey decreased the DNA damaged cause by } \\
\text { food mutagen induced in HepG2 cell. }\end{array}$ \\
\hline Ahmad et al. (2012) & $\begin{array}{l}\text { Murine epidermal keratinocyte cell } \\
\text { line (PAM212) }\end{array}$ & Tualang honey & Western blot & $\begin{array}{l}\text { Tualang honey decrease the number of DNA } \\
\text { repair protein. }\end{array}$ \\
\hline Zhou et al. (2012) & $\lambda \mathrm{DNA}(\mathrm{pBR} 322)$ & $\begin{array}{l}\text { Buckwheat } \\
\text { honey }\end{array}$ & $\begin{array}{l}\text { DNA fragmented } \\
\text { assay }\end{array}$ & $\begin{array}{l}\text { Honey protect DNA from being damaged by } \\
\text { hydroxyl radical. }\end{array}$ \\
\hline Wen et al. (2012) & Colon carcinoma cell line & $\begin{array}{l}\text { Gelam and } \\
\text { Nenas honey }\end{array}$ & $\begin{array}{l}\text { Alkaline Comet } \\
\text { assay }\end{array}$ & $\begin{array}{l}\text { At high concentration, both honey increased } \\
\text { DNA damaged of colon carcinoma cell line. }\end{array}$ \\
\hline Suzana Makpol (2012) & Human diploid fibroblast & Gelam honey & $\begin{array}{l}\text { Alkaline Comet } \\
\text { assay }\end{array}$ & $\begin{array}{l}\text { Gelam honey decreased DNA damaged in } \\
\text { human diploid fibroblast cell line. }\end{array}$ \\
\hline Tsai et al. (2012) & $\begin{array}{l}\text { Gastric adenocarcinoma cell and } \\
\text { human lung adenocarcinoma cell }\end{array}$ & Propolis & $\begin{array}{l}\text { Alkaline Comet } \\
\text { assay }\end{array}$ & $\begin{array}{l}\text { Propolis can caused DNA damaged in presence } \\
\text { of } \mathrm{Fe}^{2+} \text { ion. }\end{array}$ \\
\hline $\begin{array}{l}\text { Mogib El-Dahtory \& } \\
\text { Yahia (2011) }\end{array}$ & Peripheral lymphocytes & Honey & $\begin{array}{l}\text { Chromosomal } \\
\text { breakage assay }\end{array}$ & $\begin{array}{l}\text { Honey decreased chromosomal breakage } \\
\text { induced by mitomycin } \mathrm{C} \text {. }\end{array}$ \\
\hline Luo et al. (2007) & $\lambda$ DNA (pBR322) & Propolis & $\begin{array}{l}\text { DNA fragmented } \\
\text { assay }\end{array}$ & Propolis reduced DNA damage in cell. \\
\hline Russo et al. (2006) & Normozoospermic semen sample & Propolis & $\begin{array}{l}\text { Alkaline Comet } \\
\text { assay }\end{array}$ & $\begin{array}{l}\text { Propolis sample possesses the capacity to } \\
\text { protect human spermatozoa from the genotoxic } \\
\text { action }\end{array}$ \\
\hline Gunduz et al. (2005) & $\begin{array}{l}\text { T-cell acute lymphoblastic } \\
\text { leukemia cell line (CCFR-CEM) }\end{array}$ & Propolis & $\begin{array}{l}\text { Telomere activity } \\
\text { assay }\end{array}$ & $\begin{array}{l}\text { Propolis decrease the activity of telomerase } \\
\text { enzyme. }\end{array}$ \\
\hline
\end{tabular}

\subsection{In vitro Studies}

Table 1 summarizes the effect of honey and its derivatives on genome health in in vitro studies. Published articles claimed that honey, propolis and bee pollen can reduce the DNA damage induced by genotoxic agent such as benzo $(\alpha)$ pyrene (Russo et al., 2006), peroxynitrate (Luo et al., 2007), hydrogen peroxide (Afroz et al., 2016; Cheng et al., 2013; Habib et al., 2014; Sherin et al., 2015; Zhou et al., 2012), chlorpyrifos (pesticide) (Alleva et al., 2016) and tertiary-butyl-hydroperoxide (Turan et al., 2015). Generally, antioxidant can scavenge free radicals and reduce the potential of oxidative damage in the cell. There was a study conducted by Zhou et al. (2012) stated that honey has a capability to protect DNA in the non-specific system from being damaged by ROS. 
In the non-specific system, plasmid DNA which present in supercoiled form decrease by $68.6 \%$ when treated with honey (Zhou et al., 2012). Propolis also has a potential to increase the expression of DNA repair enzyme such as hOGG-1 and NEIL-1 (Turan et al., 2015). However, the protective effect by honey toward oxidative damage are mostly from flavonoid content in honey and its derivates (Alleva et al., 2016; Cheng et al., 2013, 2017; Russo et al., 2006; Sherin et al., 2015; Tsai et al., 2012). Propolis that contain flavonoid content such as galangin, pinochembrin, and chrysin have capability to reduce oxidative DNA damage thus become the one of beneficial factor of the propolis (Tsai et al., 2012).

Drugs can be genotoxic to the cell either it can break the chromosome (Mogib El-Dahtory \& Yahia, 2011) or develop other cancer (Yaacob \& Ismail, 2014). Although it can treat a targeted disease, it slightly can induce oxidative damage caused by its byproduct during biological process (Fahmy et al., 2015). There were studies on the effect of honey to reduce the genotoxic effect induced by mitomycin-C and tamoxifen (Mogib El-Dahtory \& Yahia, 2011; Yaacob \& Ismail, 2014). In the study, antioxidant content from the honey can reduce the chromosomal breakage and increase DNA repair protein induced by mitomycin-C and tamoxifen (Mogib El-Dahtory \& Yahia, 2011; Yaacob \& Ismail, 2014).

Radiation either in natural form or human made can trigger the formation of free radical and can slightly damage the cell (Yalcin et al., 2016). The effectiveness of honey and propolis to reduce the DNA damage on fibroblast cell had been studied and both tested compounds have potentials' to be radioprotective agent to reduce the oxidative damage (Suzana, 2012; Yalcin et al., 2016). A study by Ahmad et al. (2012), stated that honey can protect keratinocyte cell line from DNA damage induced and enhance DNA repaired by increased the activity of DNA repair enzyme such as OGG1 enzyme (Ahmad et al., 2012).

From the studies done by Haza and Morales (2013), honey with higher phenolic compound is able to reduce DNA damage cause by food mutagens. When they compare with artificial honey that mimic the sugar content in pure honey, artificial honey does not reduce DNA damage when induced with food mutagens. This suggests the protective effect of honey might come from its phenolic compound (Haza \& Morales, 2013).

Honey and propolis also has been used to suppress the cancer cell by inducing the DNA damage (Gunduz et al., 2005; Roberto et al., 2016; Wen et al., 2012). It can reduce the production of hydrogen peroxide during inflammation process (Wen et al., 2012). In addition, study conducted by Gunduz et al. (2005), proposed the mechanism underlying the effect of propolis on the leukemic cell line in which human telomerase reverse transcriptase (hTERT) significantly decreased after following treatment with propolis.

\subsection{In vivo Studies}

The clinical findings reported that honey, royal jelly, propolis and bee pollen can reduce DNA damage by using in vivo approaches (Table 2). There are several agent that can cause DNA damage such as mitomycin-C (Kumari et al., 2017), cyclophosphamide (Fahmy et al., 2015), carbon tetrachloride $\left(\mathrm{CCl}_{4}\right)(\mathrm{Cheng}$ et al., 2015), malathion (Kandiel et al., 2014), alloxan (2,4,5,6-tetraoxypyrimidine; 5,6-dioxyuracil) (Oršolić et al., 2013), 2,3,7,8tetrachlorodibenzo-p-dioxin (Türkez et al., 2013), cadmium (Cavuşoğlu et al., 2009), pesticides (Alleva et al., 2016), peroxynitrate (Luo et al., 2007), hydrogen peroxide (Russo et al., 2006) and dimethylhydrazine (Alves De Lima et al., 2005).

Generally, most of the literatures use the honey or its derivates to reduce the reactive oxygen species (ROS) resulted from the usage of drug to treat several treatments. Mitomycin-C is a drug for treat diseases related to pancreatic, gastric, breast, prostate and bladder cancer (Verweij \& Pinedo, 1990) meanwhile cyclophosphamide was used to treat cancer and autoimmune disease. These drugs originally were not in toxic form but when it undergoes enzymatic reduction process in biological system the secondary product will lead to DNA damage (Fahmy et al., 2015; Kumari et al., 2017) and lead to genetic mutation. Study conducted by Kumari et al. (2017) and Fahmy et al. (2015) proposed that mice treated with mytomycin-C and cyclophosphamide will reduce the DNA damage when following treatment with propolis and royal jelly.

Honey and it derivatives were able to reduce DNA damage when the mice was induced with toxins such as carbon tetrachloride $\left(\mathrm{CCl}_{4}\right)$, alloxan and dimethylhydrazine (Alves De Lima et al., 2005; Cheng et al., 2015; Oršolić et al., 2013). These agents can cause carcinogenesis and may lead to various diseases (Alves De Lima et al., 2005). However, pretreatment with honey or its derivatives decreased the DNA damage as reported in their studies respectively. The studies suggests that antioxidant capacity from honey and its derivates may scavenge the free radicals derives from the toxins (Afroz et al., 2016; Alves De Lima et al., 2005; Cheng et al., 2013, 2015; Habib et al., 2014; Oršolić et al., 2013; Roberto et al., 2016; Sherin et al., 2015). 
Ionizing radiation also can cause DNA damage when interacting with living cells (Benkovic et al., 2008; Suzana, 2012). Degree of damage depends on time exposure, absorbance dose and susceptibility of the tissue toward the radiation (Benkovic et al., 2008). Due to broad spectrum of biological properties of honey and its derivatives, study conducted by Benkovic et al. (2008) use propolis to diminish DNA damage in white blood cell of mice that exposed to radiation. Mice that following treatment with propolis have significantly lower in comet tail length and comet tail intensity compared to untreated group (Benkovic et al., 2008).

Reactive oxygen species (ROS) are always attributed to aging and excessive physical exercise (Hajizadeh Maleki et al., 2016; Sahhugi et al., 2014). Although aging is a declined physiological process, but ROS also have an important role to speed up aging process. Previous studies reported that honey can reduce oxidative damage in rats and decrease the level of DNA damage (Jubri et al., 2013; Sahhugi et al., 2014; Yao et al., 2011). Meanwhile, study by Hajizadeh Maleki et al. (2016) stated that consumption of honey can inhibit oxidative stress and decrease DNA damage after exercise training in road cyclist. The subjects were took $70 \mathrm{~g}$ honey in $250 \mathrm{ml}$ distilled water before training session and after the exercise, blood were taking for analysis and there showed a decrease in lymphocytes DNA damage (Hajizadeh Maleki et al., 2016).

In contrast, there was a report on mutagenic effect of propolis from Brazil study by Pereira et al. (2008). From our knowledge and authors claim, this is the first in vivo report of propolis's negative effect. At concentration from $1000 \mathrm{mg} / \mathrm{kg}$ dose until $2000 \mathrm{mg} / \mathrm{kg}$, these doses were found to induce DNA damage on the blood cell of tested mice as measured by alkaline comet assay ( Pereira et al., 2008).

\section{Discussion}

Thirty-four published articles on the current knowledge on honey and its derivatives with genome health were identified for this review. Honey and its derivatives was found to have potential to reduce DNA damage in cell as well as in biological system thus reducing risk of diseases related to genomic instability (Figure 2).

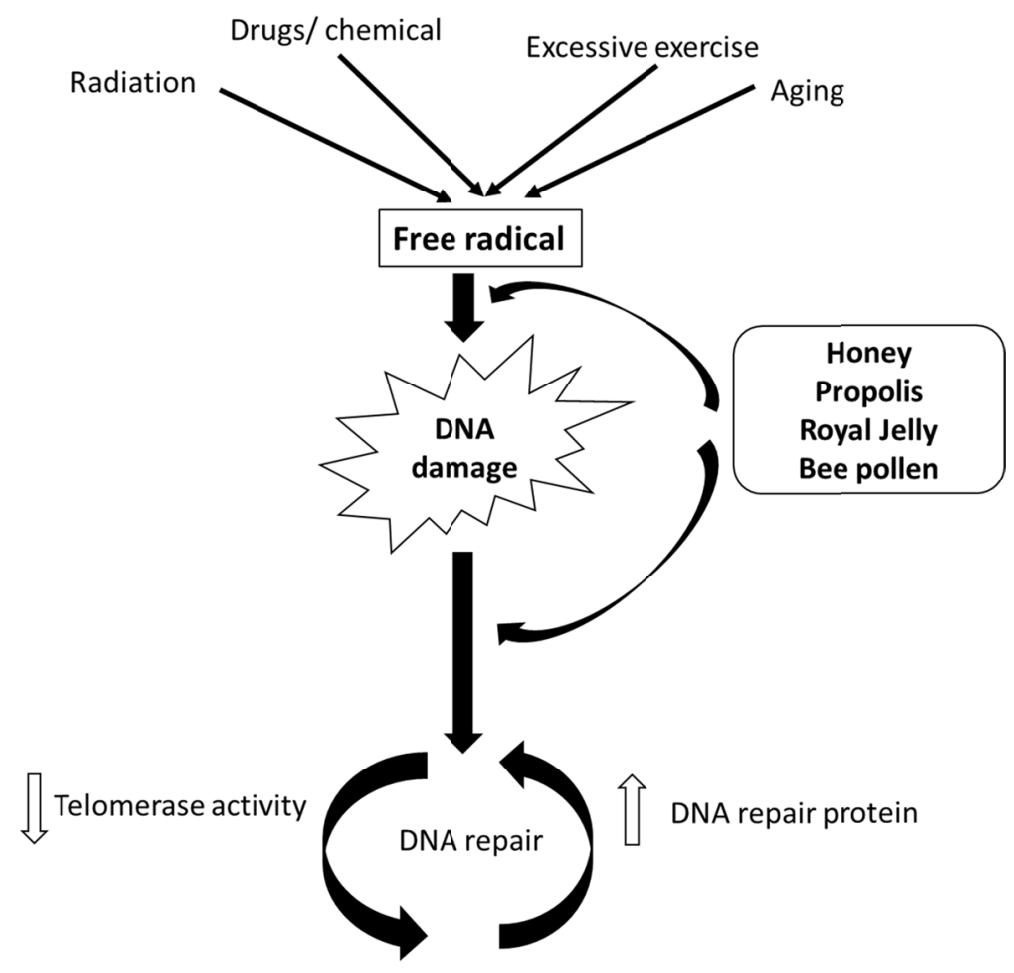

Figure 2. Schematic diagram on the protection effect of honey and its derivatives to decrease DNA damage to enhance better life

There were a lot of causative agents that able to increase the reactive oxygen species in biology system. DNA damage happened when oxidative stress increases the production of free radicals that can cause oxidative damage to protein, fat and DNA itself. Human diet that contains food mutagens can also cause DNA damage. Nitrosamines is an example of food mutagens that can be found in variety of food such as bacon, ham, sausage, 
cheese and many more (Haza \& Morales, 2013). Meanwhile heterocyclic amines and polycyclic aromatic hydrocarbons were formed when fish or meat were cooked at high temperature. Both mutagens can induce DNA damage and able to develop carcinogenesis (Haza \& Morales, 2013). DNA damage can increase the probability of causing a genomic instability and lead to mutation.

Recently, environment pollutions increased due to industrial revolutions. Toxic chemical discharged from industrial and may enter biological system and disturb biochemical process thus lead to various diseases (Cavuşoğlu et al., 2009; Kandiel et al., 2014). Cadmium, malathion and 2,3,7,8-tetrachlorodibenzo-p-dioxin were the common environment contaminant (Cavuşoğlu et al., 2009; Kandiel et al., 2014; Türkez et al., 2013) which have a toxic effect and cause DNA damage. However, usage of bee pollen, propolis and royal jelly can reduce the genotoxicity effect. Moreover, they used bee pollen with the crushed commercial basal diet for Nile tilapia to reduce toxicity effect of malathion in agricultural setting (Kandiel et al., 2014).

Briefly from this review, two types of outcomes have been proposed. Most of the published articles showed that the honey and its derivatives can reduce the DNA damage by scavenging of the reactive oxygen species (ROS) when cell or mice were induced with genotoxic agents (Cheng et al., 2015, 2017; Kumari et al., 2017; Zhou et al., 2012). Reducing or inhibiting the free radical can decrease the potential of having genotoxic related diseases such as cancer, inflammation disorder and cardiovascular disease (Wen et al., 2012). Reducing of free radical were associated with the flavonoid content in the honey and its derivatives (Tsai et al., 2012). There was a correlation between the total bioactive compound and the protective effect towards DNA damage; higher total phenolic shown strongest protection to the DNA molecules (Cheng et al., 2017).

The others studies done by Yaacob et al. (2014) and Cheng et al. (2017) proposed that honey can decrease oxidative damage caused by progression of cancer cell. Honey can become cytotoxic to the cancer cell similar as tamoxifen, a drug for treatment breast cancer but, at the same time it can reduce formation of free radicals during the biological process (Yaacob \& Ismail, 2014). Consumption of any drug can lead to several side effects to health such as development of other diseases at different drug targeted (Fahmy et al., 2015; Mogib El-Dahtory \& Yahia, 2011) due to the byproduct formation. Nevertheless, propolis was found to cause damage on DNA molecules when used in higher doses (Pereira et al., 2013).

However, honey and its derivates either propolis, royal jelly or bee pollen had beneficial effects when taking in proper doses. It can decrease the free radical effect by chemical, environment, or it also can become a good anti-cancer agent. Surprisingly, honey and its derivatives can also increase the expression of DNA repair genes such as hOGG-1 and NEIL-1 (Turan et al., 2015). That are responsible for repairmen of single-strand cleavage resulted from oxidative damage by free radicals (Turan et al., 2015). Besides that, propolis also plays a role to decrease the expression of telomerase activity in leukemic cell line (Gunduz et al., 2005). This suggests that propolis can protect damage that lead to the apoptosis by inhibiting the expression of telomerase (Gunduz et al., 2005).

Nevertheless, there are very few studies on the effect of honey and its derivatives towards DNA repair protein and telomerase activity. Most studies conducted only focusing on the effect of honey and its derivatives on DNA damage induced by free radicals and the effectiveness to suppress cancer cell. The mechanism underlying the effect of honey and its derivates to prevent the cell to undergo DNA damage need to be addressed in further investigation.

\section{Conclusion}

From the studies, honey and its derivatives showed a potential candidate to prevent oxidative damage on DNA thus provide the stability of the genome for better health maintenance.

\section{References}

Afroz, R., Tanvir, E. M., Paul, S., Bhoumik, N. C., Gan, S. H., \& Khalil, M. I. (2016). DNA Damage Inhibition Properties of Sundarban Honey and its Phenolic Composition. Journal of Food Biochemistry, 40(4), 436-445. https://doi.org/10.1111/jfbc. 12240

Ahmad, I., Jimenez, H., Yaacob, N. S., \& Yusuf, N. (2012). Tualang Honey protects keratinocytes from ultraviolet radiation induced inflammation and DNA damage. Photochemistry and Photobiology, 88(5), 1198-1204. https://doi.org/10.1111/j. 1751-1097.2012.01100.x

Alleva, R., Manzella, N., Gaetani, S., Ciarapica, V., Bracci, M., Caboni, M. F., ... Pasini, F. (2016). Organic honey supplementation reverses pesticide-induced genotoxicity by modulating DNA damage response. Molecular Nutrition and Food Research, 60(10): 2243-2255. https://doi.org/10.1002/mnfr.201600005 
Alves De Lima, R. O., Bazo, A. P., Said, R. A., Sforcin, J. M., Bankova, V., Darros, B. R., \& Salvadori, D. M. F. (2005). Modifying effect of propolis on dimethylhydrazine-induced DNA damage but not colonic aberrant crypt foci in rats. Environmental and Molecular Mutagenesis, 45(1), 8-16. https://doi.org/10.1002/em.20082

Benkovic, V., Orsolic, N., Knezevic, A. H., \& Ramic, S. (2008). Evaluation of the radioprotective effects of propolis and flavonoids in gamma-irradiated mice: The alkaline comet assay study. Biological \& Pharmaceutical Bulletin, 31(1), 167-172. https://doi.org/10.1248/bpb.31.167

Cavuşoğlu, K., Yapar, K., \& Yalçin, E. (2009). Royal jelly (honey bee) is a potential antioxidant against cadmium-induced genotoxicity and oxidative stress in albino mice. Journal of Medicinal Food, 12(6), 1286-1292. https://doi.org/10.1089/jmf.2008.0203

Cheng, N., Wang, Y., \& Cao, W. (2017). The Protective Effect of Whole Honey and Phenolic Extract on Oxidative DNA Damage in Mice Lymphocytes Using Comet Assay. Plant Foods for Human Nutrition, 72(4), 388-395. https://doi.org/10.1007/s11130-017-0634-1

Cheng, N., Wang, Y., Gao, H., Yuan, J., Feng, F., Cao, W., \& Zheng, J. (2013). Protective effect of extract of Crataegus pinnatifida pollen on DNA damage response to oxidative stress. Food and Chemical Toxicology, 59, 709-714. https://doi.org/10.1016/j.fct.2013.07.015

Cheng, N., Wu, L., Zheng, J., \& Cao, W. (2015). Buckwheat Honey Attenuates Carbon Tetrachloride-Induced Liver and DNA Damage in Mice. Evidence-based Complementary and Alternative Medicine, $2015,987385$. https://doi.org/10.1155/2015/987385

Duthie, S. J., Ma, A., Ross, M. A., \& Collins, A. R. (1996). Antioxidant Supplementation Decreases Oxidative DNA Damage in Human. Cancer Research, 56(6), 1291-1296.

Fahmy, M. A., Hassan, N. H. A., El-Fiky, S. A., \& Elalfy, H. G. (2015). A mixture of honey bee products ameliorates the genotoxic side effects of cyclophosphamide. Asian Pacific Journal of Tropical Disease, 5(8), 638-644. https://doi.org/10.1016/S2222-1808(15)60904-5

Gunduz, C., Biray, C., Kosova, B., Yilmaz, B., Eroglu, Z., \& Fahri, S. (2005). Evaluation of Manisa propolis effect on leukemia cell line by telomerase activity. Leukemia Research, 29(11), 1343-1346. https://doi.org/ 10.1016/j.leukres.2005.04.010

Habib, H. M., Al Meqbali, F. T., Kamal, H., Souka, U. D., \& Ibrahim, W. H. (2014). Physicochemical and biochemical properties of honeys from arid regions. Food Chemistry, 153, 35-43. https://doi.org/10.1016/ j.foodchem.2013.12.048

Hajizadeh Maleki, B., Tartibian, B., Mooren, F. C., Krüger, K., FitzGerald, L. Z., \& Chehrazi, M. (2016). A randomized controlled trial examining the effects of 16 weeks of moderate-to-intensive cycling and honey supplementation on lymphocyte oxidative DNA damage and cytokine changes in male road cyclists. Cytokine, 88, 222-231. https://doi.org/10.1016/j.cyto.2016.09.016

Haza, A. I., \& Morales, P. (2013). Spanish honeys protect against food mutagen-induced DNA damage. Journal of the Science of Food and Agriculture, 93(12), 2995-3000. https://doi.org/10.1002/jsfa.6129

Hoeijmakers, J. H. J. (2009). DNA Damage, Aging, and Cancer. New England Journal of Medicine, 361, 1475-1485. https://doi.org/10.1056/NEJMra0804615

Jubri, Z., Rahim, N., \& Aan, G. (2013). Manuka honey protects middle-aged rats from oxidative damage. Clinics, 68(11), 1446-1454. https://doi.org/10.6061/clinics/2013(11)11

Kandiel, M. M. M., El-Asely, A. M., Radwan, H. A., \& Abbass, A. A. (2014). Modulation of genotoxicity and endocrine disruptive effects of malathion by dietary honeybee pollen and propolis in Nile tilapia (Oreochromis niloticus). Journal of Advanced Research, 5(6), 671-684. https://doi.org/10.1016/j.jare. 2013.10.004

Khuzaimah, A., Hadju, V., As, S., Abdullah, N., Bahar, B., \& Riu, D. S. (2015). Effect of Honey and Moringa Oleifera Leaf Extracts Supplementation for Preventing DNA Damage in Passive Smoking Pregnancy. International Journal of Sciences: Basic and Applied Research, 24(1), 138-145.

Kumari, S., Nayak, G., Lukose, S. T., Kalthur, S. G., Bhat, N., Hegde, A. R., ... Mutalik, S. (2017). Indian propolis ameliorates the mitomycin $\mathrm{C}$-induced testicular toxicity by reducing DNA damage and elevating the antioxidant activity. Biomedicine and Pharmacotherapy, 95(May), 252-263. https://doi.org/10.1016/ j.biopha.2017.08.065 
Kustiawan, P. M., Puthong, S., Arung, E. T., \& Chanchao, C. (2014). In vitro cytotoxicity of Indonesian stingless bee products against human cancer cell lines. Asian Pacific Journal of Tropical Biomedicine, 4(7), 549-556. https://doi.org/10.12980/APJTB.4.2014APJTB-2013-0039

Lombard, D. B., Chua, K. F., Mostoslavsky, R., Franco, S., Gostissa, M., \& Alt, F. W. (2005). DNA repair, genome stability, and aging. Cell, 120(4), 497-512. https://doi.org/10.1016/j.cell.2005.01.028

Luo, Y., Liu, L., Gong, P., \& Zhong, R. (2007). Effect of Inhibition of Water-Soluble Propolis Induced by Peroxynitrte.

Mogib El-Dahtory, F. A., \& Yahia, S. (2011). Cytoprotective effect of honey against chromosomal breakage in fanconi anemia patients in vitro. Indian Journal of Human Genetics, 17(2), 77. https://oi.org/10.4103/ 0971-6866.86184

Oršolić, N., Sirovina, D., Gajski, G., Garaj-Vrhovac, V., Jazvinšćak Jembrek, M., \& Kosalec, I. (2013). Assessment of DNA damage and lipid peroxidation in diabetic mice: Effects of propolis and epigallocatechin gallate (EGCG). Mutation Research, 757(1), 36-44. https://doi.org/10.1016/j.mrgentox. 2013.04.022

Pereira, A. D., de Andrade, S. F., de Oliveira Swerts, M. S., \& Maistro, E. L. (2008). First in vivo evaluation of the mutagenic effect of Brazilian green propolis by comet assay and micronucleus test. Food and Chemical Toxicology, 46(7), 2580-2584. https://doi.org/10.1016/j.fct.2008.04.001

Pereira, C., Barros, L., Vilas-Boas, M., \& Ferreira, I. C. F. R. (2013). Potentiating effects of honey on antioxidant properties of lemon-flavoured black tea. International Journal of Food Sciences and Nutrition, 64(2), 230-234. https://doi.org/10.3109/09637486.2012.713916

Pérez-pérez, E., Vit, P., \& Huq, F. (2013). Flavonoids and polyphenols in studies of honey antioxidant activity. International Journal of Medicinal Plant and Alternative Medicine, 1(4), 63-72.

Roberto, M. M., Matsumoto, S. T., Jamal, C. M., Malaspina, O., \& Marin-Morales, M. A. (2016). Evaluation of the genotoxicity/mutagenicity and antigenotoxicity/antimutagenicity induced by propolis and Baccharis dracunculifolia, by in vitro study with HTC cells. Toxicology in vitro, 33, 9-15. https://doi.org/ 10.1016/j.tiv.2016.02.005

Russo, A., Troncoso, N., Sanchez, F., Garbarino, J. A., \& Vanella, A. (2006). Propolis protects human spermatozoa from DNA damage caused by benzo[a]pyrene and exogenous reactive oxygen species. Life Sciences, 78(13), 1401-1406. https://doi.org/10.1016/j.lfs.2004.10.085

Sahhugi, Z., Hasenan, S. M., \& Jubri, Z. (2014). Protective effects of gelam honey against oxidative damage in young and aged rats. Oxidative Medicine and Cellular Longevity, 19, 673628-673628. https://doi.org/ $10.1155 / 2014 / 673628$

Sharif, R., Thomas, P., Zalewski, P., \& Fenech, M. (2012). The role of zinc in genomic stability. Mutat Res, 733(1-2), 111-121. https://doi.org/10.1016/j.mrfmmm.2011.08.009

Shen, Z. (2011). Genomic instability and cancer: An introduction. Journal of Molecular Cell Biology, 3(1), 1-3. https://doi.org/10.1093/jmcb/mjq057

Sherin, M. S., Benny, B., \& Ashadevi, S. (2015). Antioxidant Activity, DNA and Cellular Protective Effect of Honey from Srilanka. Asian Journal of Biochemistry, 10(3), 106-116. https://doi.org/10.3923/ajb.2015. 106.116

Suzana, M. (2012). Gelam honey acting as a radioprotectant agent in gamma-irradiated human diploid fibroblasts. Journal of Medicinal Plants Research, 6(1), 129-138. https://doi.org/10.5897/JMPR11.1322

Tsai, Y. C., Wang, Y. H., Liou, C. C., Lin, Y. C., Huang, H., \& Liu, Y. C. (2012). Induction of oxidative DNA damage by flavonoids of propolis: Its mechanism and implication about antioxidant capacity. Chemical Research in Toxicology, 25(1), 191-196. https://doi.org/10.1021/tx200418k

Turan, İ., Değer, O., Aliyazicioğlu, Y., Demir, S., Kilinç, K., \& Sümer, A. (2015). Effects of Turkish propolis on expression of hOGG-1 and NEIL-1. Turkish Journal of Medical Sciences, 45(4), 804-811. https://doi.org/ 10.3906/sag-1406-98

Türkez, H., Geyikoğlu, F., Yousef, M. I., Toğar, B., \& Vançelik, S. (2013). Propolis alleviates 2,3,7,8-Tetrachlorodibenzo-p-dioxin-induced histological changes, oxidative stress and DNA damage in rat liver. Toxicology and Industrial Health, 29(8), 677-85. https://doi.org/10.1177/0748233712440139 
Verweij, J., \& Pinedo, H. M. (1990). Mitomycin C: mechanism of action, usefulness and limitations. Anti-Cancer Drugs, 1(August), 5-13. https://doi.org/10.1097/00001813-199010000-00002

Wen, C. T. P., Hussein, S. Z., Abdullah, S., Karim, N. A., Makpol, S., \& Yusof, Y. A. M. (2012). Gelam and nenas honeys inhibit proliferation of HT 29 colon cancer cells by inducing DNA damage and apoptosis while suppressing inflammation. Asian Pacific Journal of Cancer Prevention, 13(4), 1605-1610. https://doi.org/10.7314/APJCP.2012.13.4.1605

Yaacob, N. S., \& Ismail, N. F. (2014). Comparison of cytotoxicity and genotoxicity of 4-hydroxytamoxifen in combination with Tualang honey in MCF-7 and MCF-10A cells. BMC Complementary and Alternative Medicine 14(1): 106. https://doi.org/10.1186/1472-6882-14-106

Yalcin, C., Aliyazicioglu, Y., Demir, S., Turan, I., Bahat, Z., Misir, S., \& Deger, O. (2016). Evaluation of the radioprotective effect of Turkish propolis on foreskin fibroblast cells. Journal of Cancer Research and Therapeutics, 12(2), 990. https://doi.org/10.4103/0973-1482.154050

Yao, L. K., Liana, S., Razak, A., Ismail, N., Fai, N. C., Asyraf, M. H., ... Asgar, M. (2011). Malaysian gelam honey reduces oxidative damage and modulates antioxidant enzyme activities in young and middle aged rats. Journal of Medicinal Plant Research, 5(23), 5618-5625.

Zhou, J., Li, P., Cheng, N., Gao, H., Wang, B., Wei, Y., \& Cao, W. (2012). Protective effects of buckwheat honey on DNA damage induced by hydroxyl radicals. Food and Chemical Toxicology, 50(8), 2766-2773. https://doi.org/10.1016/j.fct.2012.05.046

\section{Copyrights}

Copyright for this article is retained by the author(s), with first publication rights granted to the journal.

This is an open-access article distributed under the terms and conditions of the Creative Commons Attribution license (http://creativecommons.org/licenses/by/4.0/). 